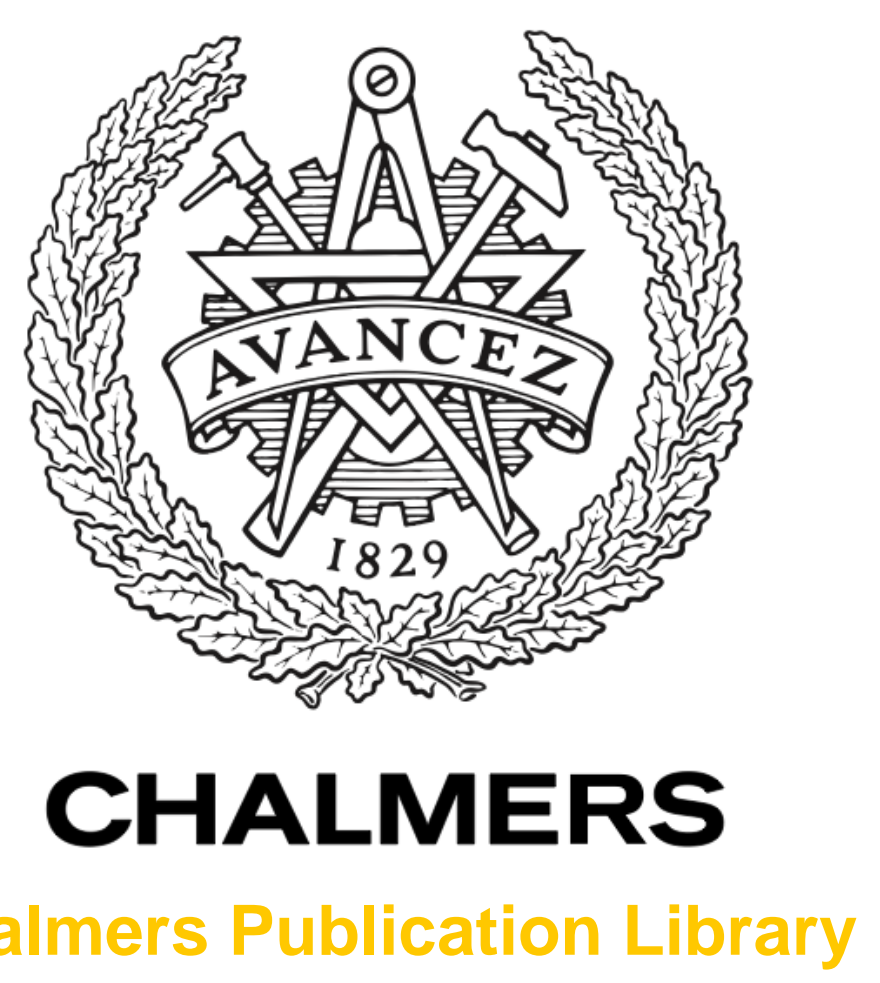

Chalmers Publication Library

\title{
Multi-faceted views on a Lean Six Sigma application
}

This document has been downloaded from Chalmers Publication Library (CPL). It is the author's version of a work that was accepted for publication in:

International Journal of Quality \& Reliability Management (ISSN: 0265-671X)

Citation for the published paper:

Assarlind, M. ; Gremyr, I. ; Bäckman, K. (2013) "Multi-faceted views on a Lean Six Sigma application". International Journal of Quality \& Reliability Management, vol. 30(4), pp. 387402.

Downloaded from: http://publications.lib.chalmers.se/publication/175799

Notice: Changes introduced as a result of publishing processes such as copy-editing and formatting may not be reflected in this document. For a definitive version of this work, please refer to the published source. Please note that access to the published version might require a subscription.

Chalmers Publication Library (CPL) offers the possibility of retrieving research publications produced at Chalmers University of Technology. It covers all types of publications: articles, dissertations, licentiate theses, masters theses, conference papers, reports etc. Since 2006 it is the official tool for Chalmers official publication statistics. To ensure that Chalmers research results are disseminated as widely as possible, an Open Access Policy has been adopted.

The CPL service is administrated and maintained by Chalmers Library. 


\title{
Multi-Faceted Views on a Lean Six Sigma Application
}

\author{
Marcus Assarlind*, marcus.assarlind@chalmers.se \\ Division of Quality Sciences, Chalmers University of Technology \\ Ida Gremyr \\ Division of Quality Sciences, Chalmers University of Technology \\ Kristoffer Bäckman \\ Solving Efeso
}

\begin{abstract}
'This article is (C) Emerald Group Publishing and permission has been granted for this version to appear at Chalmers publication library. Emerald does not grant permission for this article to be further copied/distributed or hosted elsewhere without the express permission from Emerald Group Publishing Limited.'
\end{abstract}

Link to publisher version: $\underline{\text { http://dx.doi.org/10.1108/02656711311308385 }}$

\begin{abstract}
Purpose - Lean and Six Sigma observers, researchers and managers are awaiting the next step, which many feel could take the form of a combination of the two concepts, known as Lean Six Sigma. The purpose of this paper is to explore an application of Lean Six Sigma in practical improvement work, as a way of identifying factors of importance for improving future Lean Six Sigma applications.

Design/methodology/approach - The empirical study was conducted through interviews, meetings, document analysis and observations over a period of four months.

Findings - The findings of this study suggest it is unfeasible to apply one standardised approach to improvements in one company. Continuous smaller improvements and larger improvement projects demand different formulas. It is appropriate to use Lean and Six Sigma in parallel but this should be done through clever cross-fertilisation, such as taking variations in project complexity into consideration.

Research limitations/implications - This paper shows one way of working with an improvement initiative in one particular company. It does not propose that this is the only way to combine Lean and Six Sigma nor does it suggest universal applicability. Further research on other possible combinations would be valuable.

Practical implications - This paper provides an outline of how to structure a combination of Lean and Six Sigma. This could provide valuable insights to managers who wish to structure their improvement processes depending on the type of problem at hand.

Originality/value - This paper expands the theoretical foundation for combining Lean and Six Sigma by studying and analysing a practical application of the concept. As a result, it provides new factors of importance for successful Lean Six Sigma applications, such as having a clear structure that guides the company in terms of what components of Lean Six Sigma to apply and what competences to involve in various projects depending on the scope and complexity.
\end{abstract}

Key Words - Lean Six Sigma, Lean, Six Sigma, process improvement, case study

Paper Type - Research paper 


\section{Introduction}

Lean and Six Sigma are popular contemporary process improvement methodologies intended for companies that strive for operational excellence (Arnheiter \& Maleyeff, 2005). Both methodologies have roots in the industrial revolution that Henry Ford started in the early $20^{\text {th }}$ century. The ideas that arose at that time were studied, modified and taken to Japan by Toyota gurus Eiji Toyoda and Taiichi Ohno (Dahlgaard \& Dahlgaard-Park, 2006). From this starting point, the concepts of Six Sigma and Lean have evolved and changed the way in which many people view improvement work (Dahlgaard \& Dahlgaard-Park, 2006; Byrne et al., 2007). However, even though these concepts have evolved in somewhat different directions, there has been considerable cross-fertilisation and a merger of the two may create room for even more.

Such a merger is often referred to as Lean Six Sigma or Lean Sigma (e.g., Antony et al., 2003; Van den Heuvel et al., 2006) and advocates often stress the complementary benefits of combining the pragmatic and value-centred Lean with the data-driven Six Sigma (Arnheiter \& Maleyeff, 2005; Kumar et al., 2008).

Most of the academic discussions to date on the topic of synergies have been theoretical. While this is a necessary starting point, it means that less attention has been devoted to the practical implications and the actual operational execution. This paper aims to explore an application of Lean Six Sigma in practical improvement work, as a way of identifying important factors for improving future Lean Six Sigma applications. The paper begins with a theoretical background of Lean Six Sigma, including the compatibility of the two underlying initiatives, the concept of Lean Six Sigma and the factors that affect its application. It then proceeds to elaborate on the methodology and outline the results of the study. The final sections of the paper contain analysis, discussion and conclusions.

\section{Lean Six Sigma}

As a background to the discussion, the paper begins with a brief overview of some of the central components of Lean Six Sigma's two underlying concepts. The components have been derived theoretically, which is one of several ways of deconstructing Six Sigma and Lean.

Six Sigma can be broken down into seven parts: DMAIC (Hoerl, 2004), Six Sigma toolbox (Magnusson et al., 2003), Six Sigma organisation (Hoerl, 2004; Bergman \& Klefsjö, 2003; Magnusson et al., 2003), Reduction of variation (Nave, 2002; Näslund, 2008; Bertels, 2008), Customer focus (Bergman \& Klefsjö, 2003), Decisions based on facts (Goh \& Xie, 2004) and Bottom line focus (Goh, 2002). Similarly, Lean can be said to be based on four concepts: Lean tools and techniques - notably Value Stream Mapping (Womack, 2006; Alukal, 2003), Involvement of people (Holbeche, 1997), Continuous improvement (Ricondo \& Viles, 2005) and Removal of waste (Spector, 2006; Alukal, 2003; Näslund, 2008).

\subsection{Compatibility of Six Sigma and Lean}

Nave (2002) argued that Six Sigma and Lean are essentially the same thing, or at least that they lead towards the same state. It can be said that the primary effect of Six Sigma is 'uniform process output' and for Lean it is 'reduced flow time'. However, secondary effects can be considered to be 'uniform process output' and 'reduced flow time' for Lean and Six Sigma, respectively. This can be a way of saying that an explicit combination of a focus on variation reduction and waste reduction is unnecessary since it is intrinsic and implied. However, it can also be an argument that such a 
combination is a natural way of achieving an appropriate, explicit and easily understandable approach, and that the simultaneous and conscious application of Lean and Six Sigma concepts can be result-enhancing. Pepper and Spedding (2010) felt that Lean was the contributor of strategy and structure that would drive improvements, while Six Sigma contained the "tools to leverage improvement to its full potential". It seems natural to combine Lean and Six Sigma, considering the common roots of the two improvement programmes (as described, for example, in Dahlgaard \& Dahlgaard-Park, 2006).

One of the observers who disagree with this theory is Bendell (2006), who acknowledged the desirability of combining the advantages of the two improvement methodologies but also identified some inherent conflicts. For example, if Lean methodologies have been used to remove waste in a process by applying quick fixes to a multitude of issues, controlling them during the Six Sigma Control phase can create considerable practical problems. In the context of Lean product development, Karlsson and Åhlström (1996) noted that the key is to acknowledge that the techniques are interrelated and that the system may not work if only a few of them are implemented. While this does not necessarily imply the need to implement packaged solutions, combining various desultory techniques without considering the system as a coherent whole may be a recipe for failure.

\subsection{What is Lean Six Sigma?}

As noted, the way in which individuals and companies view Lean Six Sigma lacks coherence. An ongoing trend is to integrate Lean and Six Sigma by adding Six Sigma projects to a Lean initiative (Hoerl, 2004). Antony et al. (2003) highlighted the strengths of the two initiatives and discussed the theoretical synergies of using both. Table 1, outlined in Antony et al. (2003), provides an overview of the focuses of both Lean and Six Sigma.

Table 1: Theoretical synergies of Six Sigma and Lean (Antony, Escamilla, \& Caine, 2003)

\begin{tabular}{|lcc|}
\hline Issue/problem/objective & Lean & Six Sigma \\
\hline Focuses on customer value stream & $\mathrm{Y}$ & $\mathrm{X}$ \\
Focuses on creating a visual workplace & $\mathrm{Y}$ & $\mathrm{X}$ \\
Creates standard work sheets & $\mathrm{Y}$ & $\mathrm{X}$ \\
Attacks work-in-process inventory & $\mathrm{Y}$ & $\mathrm{X}$ \\
Focuses on good house keeping & $\mathrm{Y}$ & $\mathrm{X}$ \\
Process control planning and monitoring & $\mathrm{X}$ & $\mathrm{Y}$ \\
Focuses on reducing variation and achieve uniform process outputs & $\mathrm{X}$ & $\mathrm{Y}$ \\
Focuses heavily on the application of statistical tools and techniques & $\mathrm{X}$ & $\mathrm{Y}$ \\
Employs a structured, rigorous and well planned problem solving & $\mathrm{X}$ & $\mathrm{Y}$ \\
methodology & $\mathrm{Y}$ & $\mathrm{X}$ \\
Attacks waste due to waiting, over processing, motion, over production, & $\mathrm{Y}$ & \\
etc. & &
\end{tabular}

Overall, it seems as though the term Lean Six Sigma could refer to the integration into one concept and to the concurrent but separate usage of both concepts. Arnheiter and Maleyeff (2005) made it clear that when they use the term Lean Six Sigma they refer to an integrated entity. This also seems to be the position of Ricondo and Viles (2005), who argued that the variability reduction focus of Six Sigma enhances the robustness of fragile Lean systems. Lean organisations should make greater use of data in decision-making but should also use methodologies that promote a more scientific approach to quality. Six Sigma organisations, meanwhile, risk providing poor service to customers 
because of the long lead times, even if they produce at Six Sigma levels (Arnheiter \& Maleyeff, 2005). However, it can be argued that Six Sigma is generic and that the intentions determine the outcome (Hoerl, 2004). In other words, if lead time is the issue then this can be assigned as the variable that requires improvement and Six Sigma can be applied 'as usual'.

In addition to the many ideas regarding the compatibility of the two concepts, there are also many different theories as to how Lean Six Sigma could be implemented. Hoerl (2004) recommends making Six Sigma the lead initiative and bringing in Lean principles to support the analysis phase. Another view is to have Lean as the standard and to use Six Sigma to investigate and eliminate any variation from this standard (Ferng \& Price, 2005).

\subsection{Applying Lean Six Sigma}

Successful applications of new ideas in an organisation are rarely trivial. This section will examine suggestions regarding the successful use of Lean Six Sigma in an organisation and identify the factors that are critical for success (critical success factor: CSF). Saraph, Benson and Schroeder (1989, p. 811) defined a critical factor as "a critical area of managerial planning and action that should be considered in order to achieve effective quality management in an organisation".

A literature review by Näslund (2008) identified CSFs for a number of operations management concepts, including Six Sigma and Lean. Näslund (2008) concluded that the CSFs offered in literature are quite similar and general for both concepts. It is important to apply this type of concept systematically, rather than in a functional, operational or ad hoc manner; this can be achieved by, for example, a process management approach (Näslund 2008). In line with the work by Näslund (2008), Table 2 reveals the CSFs of an integrated Lean Six Sigma approach, as well as related barriers and benefits. Table 2 is based on research papers that report on practical applications of Lean Six Sigma.

CSFs for implementing Lean Six Sigma can be found in many areas. The grouping of CSFs in Table 2 reveals a cluster of CSFs that does not seem specific to Lean Six Sigma; rather it considers general implementation issues. In other words, much can be learned from the implementation of various other improvement initiatives with regard to management support, communication and change. Some of the other cited CSFs are more unique to the Lean Six Sigma context and are related to training, application of a Six Sigma structure with trained specialists (the so-called belts), a projectby-project approach and measurable targets that can facilitate documentation of project successes used in a phased implementation. 
Table 2: Critical Success Factors, barriers and benefits of Lean Six Sigma

\begin{tabular}{|c|c|c|c|c|c|c|c|c|}
\hline & $\begin{array}{l}\text { Fornari } \\
\text { et al. } \\
(2004)\end{array}$ & $\begin{array}{l}\text { Van den } \\
\text { Heuvel et } \\
\text { al. (2006) } \\
\end{array}$ & $\begin{array}{l}\text { Byrne et } \\
\text { al. (2007) }\end{array}$ & $\begin{array}{l}\text { Pickrell et } \\
\text { al. (2005) }\end{array}$ & $\begin{array}{l}\text { de Koning } \\
\text { et al. } \\
(2008) \\
\end{array}$ & $\begin{array}{l}\text { Kumar } \\
\text { et al. } \\
(2006) \\
\end{array}$ & $\begin{array}{l}\text { de Koning } \\
\text { et al. } \\
(2006)\end{array}$ & $\begin{array}{l}\text { Carleysmith } \\
\text { et al. (2009) }\end{array}$ \\
\hline \multicolumn{9}{|l|}{ Critical Success Factors } \\
\hline $\begin{array}{l}\text { Management support \& } \\
\text { commitment }\end{array}$ & $\mathrm{x}$ & & & & & $\mathrm{x}$ & & $\mathrm{x}$ \\
\hline $\begin{array}{l}\text { Information, } \\
\text { communication and } \\
\text { knowledge sharing }\end{array}$ & $\mathrm{x}$ & & & & & $\mathrm{x}$ & & $\mathrm{x}$ \\
\hline $\begin{array}{l}\text { Culture change, use facts } \\
\text { to show need for change }\end{array}$ & $\mathrm{x}$ & & & & & $\mathrm{x}$ & & $\mathrm{x}$ \\
\hline $\begin{array}{l}\text { Staff involvement, } \\
\text { rewards and recognition }\end{array}$ & & & & & & $\mathrm{x}$ & & $\mathrm{x}$ \\
\hline $\begin{array}{l}\text { Projects linked to } \\
\text { company goals }\end{array}$ & $\mathrm{x}$ & & & & & & $\mathrm{x}$ & \\
\hline $\begin{array}{l}\text { Phased implementation; } \\
\text { building on success, } \\
\text { ensuring sustained } \\
\text { improvements }\end{array}$ & & & & & & $\mathrm{x}$ & & $\mathrm{x}$ \\
\hline Six Sigma infrastructure & $\mathrm{x}$ & & & & & & $\mathrm{x}$ & \\
\hline $\begin{array}{l}\text { Apply Lean tools both in } \\
\text { projects and outside }\end{array}$ & & & & & & & & $\mathrm{x}$ \\
\hline Training & & & $\mathrm{x}$ & & & & $\mathrm{x}$ & $\mathrm{x}$ \\
\hline \multicolumn{9}{|l|}{ Barriers } \\
\hline $\begin{array}{l}\text { Too large, or expanding, } \\
\text { project scope }\end{array}$ & $\mathrm{x}$ & & & $\mathrm{x}$ & & & & \\
\hline $\begin{array}{l}\text { Projects not aligned to } \\
\text { business needs }\end{array}$ & $\mathrm{x}$ & & & & & & & \\
\hline $\begin{array}{l}\text { Difficulties getting the } \\
\text { best people involved }\end{array}$ & $\mathrm{x}$ & & & & & & & \\
\hline $\begin{array}{l}\text { Lack of understanding of } \\
\text { the benefits among } \\
\text { senior management and } \\
\text { functional experts }\end{array}$ & & & & & & $\mathrm{x}$ & & $\mathrm{x}$ \\
\hline Change resistance & & & & & & $\mathrm{x}$ & & $\mathrm{x}$ \\
\hline $\begin{array}{l}\text { No standardised Lean } \\
\text { Six Sigma approach }\end{array}$ & & & & & & $\mathrm{x}$ & & \\
\hline \multicolumn{9}{|l|}{ Benefits* } \\
\hline $\begin{array}{l}\text { Addressing key customer } \\
\text { issues }\end{array}$ & $\mathrm{x}$ & & & & & & & \\
\hline $\begin{array}{l}\text { Improved process/ } \\
\text { product quality }\end{array}$ & & $\mathrm{x}$ & & $\mathrm{x}$ & $\mathrm{x}$ & $\mathrm{x}$ & & \\
\hline Reduced cycle time & & & & $\mathrm{x}$ & $\mathrm{x}$ & & & \\
\hline Reduced waste & & $\mathrm{x}$ & & $\mathrm{x}$ & $\mathrm{x}$ & & $\mathrm{x}$ & $\mathrm{x}$ \\
\hline $\begin{array}{l}\text { Develop organisational } \\
\text { ability for innovation }\end{array}$ & & & & & $\mathrm{x}$ & & $\mathrm{x}$ & \\
\hline $\begin{array}{l}\text { Impetus for using best } \\
\text { practice }\end{array}$ & & & & & & $\mathrm{x}$ & & \\
\hline $\begin{array}{l}\text { Provide a performance } \\
\text { benchmark }\end{array}$ & & & & & & $\mathrm{x}$ & & \\
\hline
\end{tabular}

*Many of the stated benefits have been reported separately as well as in terms of their resulting financial savings. This table has not reported financial savings as a separate benefit.

Although the barriers to a Lean Six Sigma implementation are rather scattered, one common denominator is that many of the discussed barriers are not related to the application of tools and methods but rather to organisational issues such as change resistance. Having a proper project scope 
and aligning it to business needs are key issues on a more operational level. The most commonly reported benefits of Lean Six Sigma are reduced waste and improved quality. This is not completely unexpected given that the concepts of waste and quality are both broad in nature and encompass a large variety of more specific benefits. One less expected benefit, which is not commonly associated with the two separate concepts of Lean and Six Sigma, is an improved organisational ability to achieve innovation.

\section{Method}

This study is based on a case study approach, which has been defined as "a research strategy which focuses on understanding the dynamics present within a single setting" (Eisenhardt 1989, p. 534). This case study focuses on one application of Lean Six Sigma in practical improvement work. As elaborated in, for example, Eisenhardt (1989), case study research typically combines various data collection methods. The empirical basis for this paper is the study of a production facility of a large Swedish manufacturing company. Two of the authors spent about three days each week on-site over a period of four months as combined internal/external consultants, aiding a specific improvement project. This time involved frequent contact with shop floor operators, improvement experts (black belts) and individuals who were tied to the development of the improvement framework. The empirical data collection is based on informal interviews, occasional meetings, documentation and observations. This kind of profound involvement helped achieve a thorough understanding of how the system actually works at the company and facilitated access to reliable information (Gummesson, 1991).

In order to explore industrial practices rather than test hypotheses, additional data was collected through semi-structured interviews, applying an interview guide that included a number of general questions but did not have a specified order (Bryman, 2001). Semi-structured interviews were conducted with seven shop-floor operators and one improvement expert. These interviews were conducted in order to further understand the perception within the company of the improvement initiative and how projects actually work. Towards the end of the company study, a semi-structured one-hour interview was conducted with an improvement initiative coordinator. This interview focused on how the improvement framework had been developed and how this framework relates to "generic" Lean and Six Sigma. Just before the completion of the paper, a complementary telephone-based interview was held with an improvement initiative coordinator to cover any remaining details.

The authors conducted data analysis to obtain insights and enhance confidence in the findings (Eisenhardt 1989). The data analysis was based on two main steps: case study write-up and thematic analysis that was inspired by, but not limited to, factors identified in Table 2 . The case study writeups were descriptive in nature and were used to condense the original amount of data and simplify the analysis (Eisenhardt, 1989). In order to strengthen the creative potential of the study and increase confidence in the findings, multiple investigators worked jointly on the analysis. One of the investigators had not been part of the data collection and was therefore able to look at the empirical data with fresh eyes (Eisenhardt, 1989). 


\section{The company-specific improvement programme}

The following is based on an empirical study of the production facility of a large company and their Lean-inspired approach to performing improvement work, which they call the 'Company Production System' (CPS) (see Figure 1).
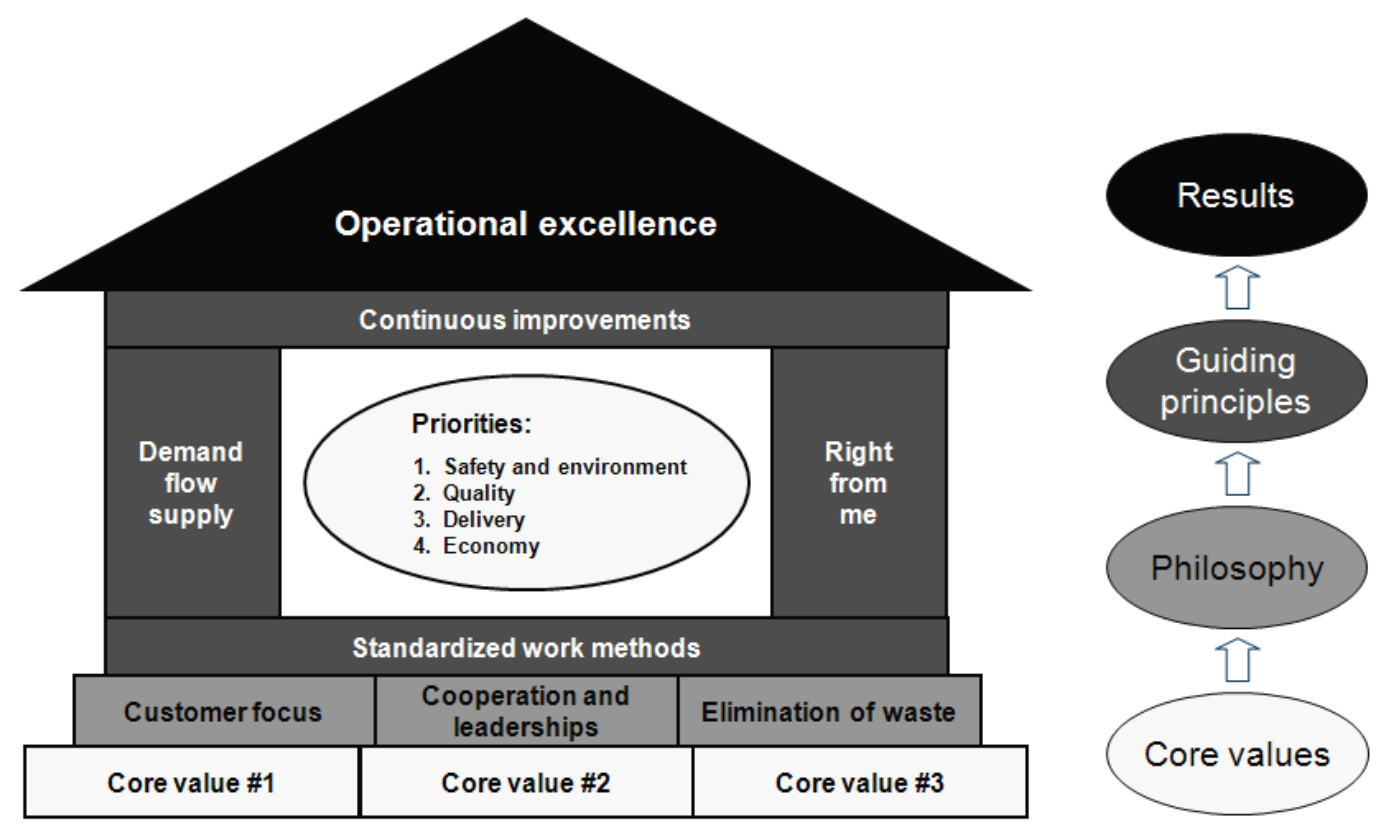

\section{Our Way of Operating}

Figure 1: The Company Production System house (Internal company documentation)

Six Sigma has quite a history in the company, dating back to the mid-1990s. At that time, Six Sigma was approach in order to be used as a remedy for product quality issues in production. It was implemented on a bottom-up basis; spreading on success, work unit to work unit; it started in assembly only and is currently spreading to all of the different functions. However, the company's management did not feel that the large improvement projects generated by the Six Sigma ideas ensured the company would be in a good position in the future. Inspired by Toyota and Scania, they implemented Lean only a few years ago as a way of involving all members of the company in continuous improvements. Lean was introduced as part of the company's new CPS initiative, in which the pre-existing Six Sigma was given a vital role. Unlike Six Sigma, CPS was introduced on a top-down basis and in most areas simultaneously.

The company's stated goal is for CPS to become a leader in terms of efficiency, problem solving, improvement work, introduction of new products and flexible production. This work towards what the company calls 'operational excellence' is guided by the principles of continuous improvements, demand flow supply, right from me and standardised work methods, all of which are designed to be in line with the philosophies of customer focus, cooperation and leadership and elimination of waste. These philosophies are, in turn, based on the company's core values.

The company describes CPS as being, essentially, a company-specific application of Lean and the Toyota Production System that encompasses appropriate methods and principles. The fact that CPS has been introduced by senior management is seen as one of its strengths because it has generated 
involvement from the upper echelons. One challenge, however, is to make everyone understand the expected power of the CPS initiative.

The central CPS office only consists of a few people, and it is the unit managers that are the ambassadors for the CPS initiative. Most of the training takes the form of "train-the-trainer"; that is, the central office trains the managers, who then train their units. The lead star of the CPS work is to organise everyone in the company, including long-term consultants, in improvement teams of six to eight people.

Running parallel to this improvement structure is an organisation that consists of improvement experts, in the form of trained Six Sigma Black Belts and Yellow Belts. In the end, the management team makes the final decisions regarding Belt training but, in practice, each unit manager decides what competence is needed in the unit and who is ready to be trained into a Black Belt or Yellow Belt. Black Belt training includes 20 days of education and the realisation of a live improvement project. Yellow Belt training involves five days plus a smaller project. The Belts are then integrated in their respective units. Yellow Belts mainly support ordinary improvement tasks in their own units with a small amount of their total time, while Black Belts devote most of their work time to handling large projects, and may also serve as company internal consultants if they are needed elsewhere.

The improvement infrastructure also includes so-called "method specialists", such as " $5 \mathrm{~S}$ specialists" or "specialists on standardised work procedures". These resources support anyone who needs help with a particular issue, even if it is a unit manager or Black Belt.

According to one interviewee from the CPS office, one of the largest challenges in the implementation is to make sure that people in the organisation understand and adopt the new ideas. This is currently being addressed by ideas such as the "train-the-trainer" concept, which uses managers and other individuals as ambassadors for the initiative. Even though CPS was introduced a few years ago, the introduction is far from finished. The company is actively working to expand its understanding of the ideas and to expand the applications. Even though it was launched in all functions at the same time, there has been greater uptake in production than in office functions.

\subsection{The Six Sigma and Lean Combination}

CPS with Lean were introduced at the company later than Six Sigma, at which point Lean and Six Sigma effectively started being used in conjunction with one another. The two systems have been incorporated into one entity, with Six Sigma's influence considered central to CPS. As an example of this centrality, the DMAIC cycle is used for all types of improvement projects. There are several types of DMAIC cycles, which are used to accommodate different needs and purposes, such as in the number of tollgates and their respective passing criteria. Another illustration of the connection between Six Sigma and Lean is that all Black Belts are trained in both systems.

One manager responsible for CPS views Lean Six Sigma not as a full integration of the two systems but rather as the simultaneous use of both through CPS. One improvement expert who has been trained in both Six Sigma and Lean says that the tools from both methodologies are mixed in order to achieve the best results. Moreover, this expert does not consider his improvement projects to be exclusively Lean or Six Sigma projects; project members utilise what is appropriate from either methodology. 
According to this CPS manager, one difference between Lean and Six Sigma is that Lean builds change through continuous incremental improvements, while Six Sigma aims for immediate breakthrough improvements. He also noted that, although Six Sigma may yield considerable improvements, the outputs of the improved processes seem to decrease gradually between projects. Based on practical experience, the CPS manager felt that Lean complements Six Sigma because it implies continuous improvements that counter decreasing performance trends that follow the finalisation of a Six Sigma project (see Figure 2).

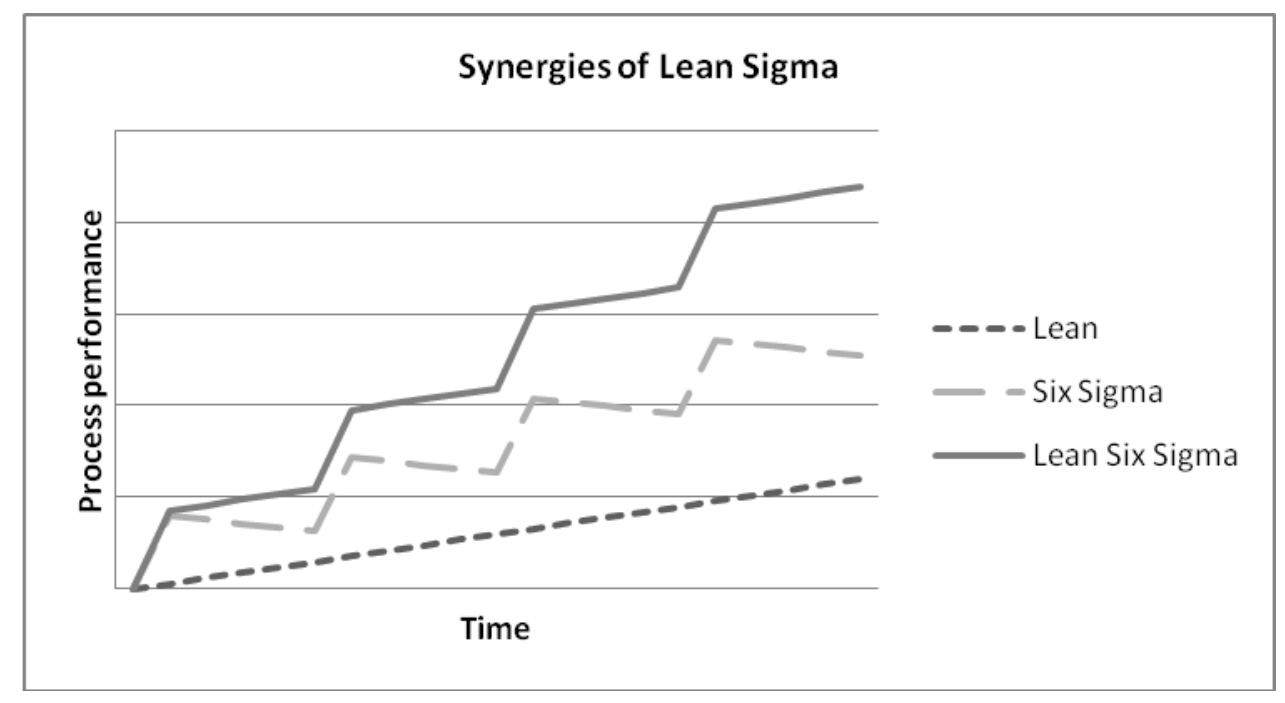

Figure 2: An interviewee's mental model of Lean and Six Sigma synergies

The interviewees seemed to see Lean more as a philosophy that focuses on eliminating waste, while Six Sigma was considered to be a tool or approach for solving generic problems. DMAIC seems to be one of the most valuable aspects of Six Sigma as it guides much of the company's improvement work. Extensive stage-gate DMAIC cycles are utilised for large projects, while simplified versions of DMAIC are used in smaller everyday improvement activities. The formalities for these simpler versions are satisfied by answering simple questions such as "What is the problem?" and "What information is needed to make a good decision?" which addresses the main DMAIC thinking. Essentially, this means that the company applies a PDCA-type approach to all improvement processes, through the use of the DMAIC cycle, with the depth varying depending on the application.

One feature of Six Sigma that was specifically noted is that it focuses on bottom-line results. One interviewee said that connecting Six Sigma thinking to any type of improvement project "gives you the power to actually prove improvements to cost or lead time".

\subsection{Practical improvement work}

Day-to-day improvements at the company are made in improvement teams that are part of a fivestep improvement hierarchy: improvement teams, expert forums, work groups, process forum and division management team (see Figure 3). Improvement teams consist of operations personnel and have weekly meetings that focus on problem identification. The group members spend a few minutes finding a suitable solution and deciding what action is to be taken and by whom. If the group is unable to solve the problem due to a lack of appropriate competence, resources or mandate, the problem is then directed to the expert forum, where operators and first-line managers work together 
to solve more complex issues. As with the first improvement teams, difficult problems can be escalated from the expert forums to the work groups and so on up to the final level, the division management. This makes it possible to take issues from the improvement teams and transform them into more Six Sigma-type improvement projects. Analogues - easily solvable problems that are identified at a higher level - can be delegated to 'lower' levels.

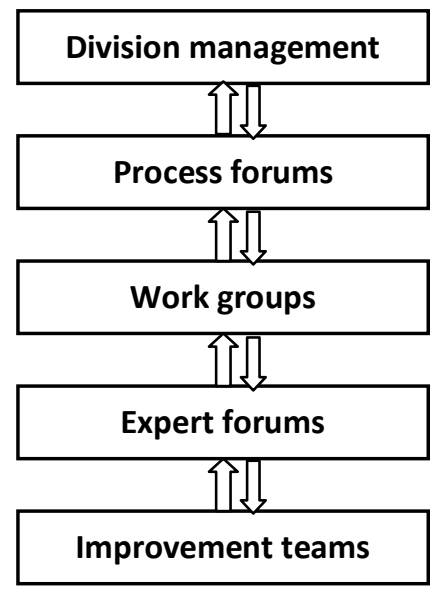

Figure 3: The company improvement hierarchy

Larger improvement projects are run by company Black Belts and are strictly prioritised based on business cases. They are usually initiated if a project seems too large to be handled at the lower levels or if it implies considerable involvement and changes across department boundaries. These projects often span several months each and resources are assigned to them many months in advance.

Another way to allocate expert improvement resources is through so-called Kaizen workshops, which any department can request. These workshops are arranged if the respective department manager, together with the management team, feels that a short-focused intervention is most appropriate for the problem. The Kaizen workshops are led by a Black Belt, last for a few days and are the sole focus for participants during this time. The overall structure of the events is a DMAIC process in which participants go through the cycle together in order to solve the problems they discover. The CPS manager highlighted the value of having Black Belts involved in these events because of their skills in using DMAIC and in implementing changes. This type of activity is considered to be better than larger projects for solving lower-level problems and is also an opportunity to provide participants with hands-on education.

Interviewees generally have a positive impression of improvement work in daily operations. Most interviewees are unfamiliar with the term 'Lean'; one interviewee related it to the regular improvement meeting held within the framework of CPS. The daily improvement team meetings are what most people think of when they hear the term CPS. The general impression of these meetings is positive. One concern was that the meetings ran the risk of becoming a competition to see who could come up with the most suggestions. Another was that performing as many changes as possible is a lead star that could risk destroying something that is already good. 
Almost all of the interviewees on the shop floor have heard of Six Sigma and they seem to mainly associate it with improvement projects and education. One of the most common associations is that the purpose of Six Sigma is to save a certain amount of money in a project. It is also perceived as being somewhat complicated and requiring extensive mathematical knowledge, which made at least one interviewee reluctant to undergo Six Sigma training. Due to its "complicated nature", one interviewee could not imagine how they would use Six Sigma in their daily work.

One interviewee compared Six Sigma and Lean by saying that Lean is about "taking the fast and smooth way to improvement" while Six Sigma is more about "discovering and fixing the worst problems". According to one interviewee, Lean requires less analysis and provides quick results but Six Sigma has a greater impact over time.

\section{Multi-Faceted Views on Lean Six Sigma}

Arnheiter and Maleyeff (2005), Hoerl (2004) and Breyfogle (1999) painted a varied picture of what Lean Six Sigma means. This paper aims to investigate and learn from one industrial application of Lean Six Sigma by capturing the company's interpretation of the concept. Even this one company has a multi-faceted view and interpretation of Lean Six Sigma that differs depending on the complexity of the improvement project and on individual differences. This generates views that range from applying Lean and Six Sigma in parallel to implementing a fully integrated system. Moreover, the integration of the concepts can take various forms, including mixing or transferring of tools, ideas and philosophies.

The experiences of de Koning et al. (2006) were that one key to success is using a Six Sigma organisational infrastructure and applying a project-by-project approach within this framework. Along the same lines, Näslund (2008) argued that a CSF for both Lean and Six Sigma is their systematic introduction in an organisation. The improvement hierarchy is an essential part of the introduction of CPS in the case company; it can be regarded not just as a hierarchy of problem solvers but also as a hierarchy of improvement project complexity. As a result, there is a clear organisational infrastructure for the Lean Six Sigma initiative, in line with de Koning et al. (2006). However, this infrastructure has been expanded to encompass not only Six Sigma belts but a variety of competences from division managers to operators. A clear infrastructure for improvement that involves all levels of an organisation helps to ensure management support (Kumar et al. 2006) and staff involvement (Carleysmith et al. 2009), both of which have been identified as critical success factors in empirical studies. Simultaneously, the direct involvement of managers is likely to be a way of overcoming barriers due to their lack of understanding of the potential benefits from this improvement initiative (Kumar et al. 2006).

Further, the improvement hierarchy can be a means of overcoming barriers in terms of project scoping, whether the scope is too large or expanding (Pickrell et al. 2005) or whether it is not aligned to business needs (Fornari et al. 2004). Involving management in the various improvement forums is one way to ensure that projects are aligned to the business needs and strategies. Moreover, if a project on a higher level expands to improve related improvement projects, these can be assigned to lower levels in the hierarchy in order to maintain focus in the original project.

Magnusson et al. (2003) described a similar hierarchy in a Six Sigma framework through the analogy of an improvement tree, in which Six Sigma is applied to complex problems and less resource- 
intensive tools are applied to less complex problems. The analogy of an improvement tree can be applied to the various views of Lean Six Sigma in the case study. The members of the improvement teams regard CPS, or Lean, as their approach to day-to-day problem solving in line with the view of Carleysmith et al. (2009), arguing that a success factor for Lean Six Sigma is to apply lean tools, both inside as outside of DMAIC improvement projects. Furthermore, the company also views Lean as a mindset that is not strictly connected to specific tools. It considers Six Sigma to be more advanced and, in some cases, non-applicable to day-to-day activities. Even so, Six Sigma is often felt to be beneficial and the Kaizen workshops are one way of linking Six Sigma improvement experts to day-today improvement work. Another way is to direct a problem upwards in the improvement hierarchy and initiate a Six Sigma project. In such a situation, an expert team would work on difficult problems but the results would be sustained in an established improvement structure that is inspired by Lean.

The CPS manager described an example of the link between Lean and Six Sigma by stating that a Lean initiative can counter a decline of Six Sigma results (as illustrated in Figure 2). However, one may argue that the decline should inherently be countered by a thorough execution of the DMAIC control phase. Nonetheless, given that this company has chosen CPS as the method for its improvement work, a direct connection between Six Sigma and Lean during the control phase seems attractive. Essentially, Lean is an integral part of the control phase in this company and used as sustain mechanisms for the improvements achieved through Six Sigma projects (Carleysmith et al. 2009).

Ideas and practical applications of combinations of Lean and Six Sigma vary between the different parts, individuals and levels of the company. As an example, the Black Belt foresees full integration of the two concepts, while the CPS manager predicts rather more distinct paths. Although this may seem contradictory, there does not need to be just one truth; it is more a matter of perspective. Black Belts, the change leaders who work hands-on with larger projects, build on a Six Sigma way of thinking while also freely utilising Lean parts (tools and ideas) thanks to their extensive training and expert knowledge. De Koning et al. (2006) and Fornari et al. (2004) noted that the view that Six Sigma and its organisational infrastructure with the belt system is a basis for Lean Six Sigma. There are other views as well, however, such as that of the CPS manager who predicted distinct paths - Six Sigma for larger tasks and Lean for everyday continuous improvements - not because of less training but because Lean is a more over-arching perspective. In addition, the participants in the improvement teams operate in a Lean-dominated world that has some Six Sigma influences, the most obvious of which is perhaps the ubiquitous DMAIC model.

\section{Discussion}

Arnheiter and Maleyeff (2005) referred to Lean Six Sigma as an integrated entity that incorporates the benefits of both Lean and Six Sigma. One rationale for implementing both systems in the case study company was to gain the benefits of continuous improvements as well as breakthrough improvements. At a company level, therefore, it can be said that the integrated use of Lean and Six Sigma does exist, although not always in individual projects. Lean and Six Sigma could be described as providing complementary, rather than synergistic, benefits. Instead of discussing whether to implement 'Lean Six Sigma', the company has selected the parts of Lean and Six Sigma that are the most appropriate for their business and adopted them into their production system.

The Lean Six Sigma application, in the form of different packages used in a wide range of projects at various levels, is intriguing. However, it is not feasible to adopt the same approach for incremental 
micro-projects performed at the lowest level by small improvement teams as you would for extensive projects performed by highly trained improvement experts. Among the reasons for this are the different problem-solving tools and expert resources that are needed. However, smaller day-today improvements can still be discussed and performed with the systematic guidance of a simplified DMAIC cycle. A more complex traditional Six Sigma approach may be appropriate for larger improvement projects. In such cases, the standard DMAIC cycle may provide structure and ensure that each step is performed thoroughly, which can aid the success of the project. Lean thinking can contribute to these projects by staking out the direction; that is, indicating where to start. For example, this could involve using value stream mapping, in which the process is reviewed in order to locate waste.

The Lean Six Sigma application in the company studied here does not point towards a specific, well defined Lean Six Sigma approach; the company does not adopt any particular standardised approach to larger improvement projects. Instead, the company supports the integration at this level by ensuring that their improvement specialists are widely trained in both Lean and Six Sigma, as integration at this level is ultimately up to the individuals. In the improvement teams, on the other hand, the dominance of Lean is obvious, although Six Sigma's influence can be seen in the idea of a ubiquitous DMAIC. This is not to say that the company does not gain complementary benefits from the two improvement initiatives; both methodologies definitely exist and thrive within the company boundary. There is also clear interaction between Lean and Six Sigma, particularly as projects are passed back and forth.

In this way, the combination of Lean and Six Sigma is beneficial in several ways. For a start, it provides separate approaches for smaller and larger projects, respectively, although ideas from any of the two approaches can be used to strengthen the other one. For example, waste reduction can be used to guide the more Six Sigma-type projects, while DMAIC can provide structure to the more Lean-type projects. Furthermore, it is seen to be beneficial to have an integrated Lean Six Sigma approach, as this can provide a platform for various types of improvement work and provide a common systematic structure for improvement work (Näslund, 2008). Lean and Six Sigma can therefore be used both concurrently and integrated at the same time.

\section{Conclusions}

Having studied this application, this paper argues that the benefits of Lean and Six Sigma can be achieved without a single, clear-cut, standardised approach towards an integrated Lean Six Sigma concept. It is, however, important to have an explicit, conscious and easily understandable approach to process improvements that are based on Lean Six Sigma. In order to best make use of both the synergies and the complementary benefits, it is essential to take a nuanced approach in which the differences are clearly acknowledged and exploited. This paper argues that a critical success factor for Lean Six Sigma is having a structure, such as an improvement hierarchy, that guides the company towards what components of Lean Six Sigma it should apply and what competences in should involve in various projects, depending on the scope and complexity. This would be a means of overcoming barriers such as a project scope that is too large or expanding, and difficulties involving the right people.

In summary, the studied company had integration between Lean and Six Sigma and applications of Lean and Six Sigma as separate initiatives. With the clear improvement hierarchy as a base, the lack 
of a standardised Lean Six Sigma approach has not been a barrier for improvements. This is not to say that the integration of the two systems cannot be developed further. The company has not yet exploited the existing knowledge of statistical methods and scientific approach within the group of Six Sigma belts in the lowest level of the improvement hierarchy - the improvement teams. One way to encourage this type of knowledge could be to ensure the presence of Six Sigma Yellow Belts (individuals with training in statistical awareness and simple tools) in all improvement teams.

\section{References}

Alukal, G. (2003), “Create a Lean Mean Machine”, Quality Progress, Vol. 36 No. 4, pp. 29-34.

Antony, J., Escamilla, J.L. and Caine, P. (2003), "Lean Sigma", Manufacturing Engineering, April), pp. 40-42.

Arnheiter, E.D. and Maleyeff, J. (2005), "The integration of lean management and Six Sigma", The TQM Magazine, Vol. 17 No. 1, pp. 5-18.

Bendell, T. (2006), "A review and comparison of six sigma and the lean organisations", The TQM Magazine, Vol. 18 No. 3, pp. 255-262.

Bergman, B. and Klefsjö, B. (2003), Quality from Customer Needs to Customer Satisfaction, Studentlitteratur, Lund.

Bertels, T. (2008), "Integrating Lean and Six Sigma - The Power Of An Integrated Roadmap", available at: http://www.isixsigma.com/library/content/c030721a.asp (accessed 16 July 2008).

Breyfogle, F.W. (1999), Implementing Six Sigma: Smarter solutions using statistical methods, Wiley, New York.

Bryman, A. (2001), Social Research Methods, Oxford University Press Inc., New York.

Byrne, G., Lubowe, D. and Blitz, A. (2007), "Using a Lean Six Sigma approach to drive innovation", Strategy \& Leadership, Vol. 35 No. 2, pp. 5-10.

Carleysmith, S.W., Dufton, A.M. and Altria, K.D. (2009), "Implementing Lean Sigma in pharmaceutical research and development: a review by practitioners", R\&D Management, Vol. 39 No. 1, pp. 95106.

Dahlgaard, J.J. and Dahlgaard-Park, S.M. (2006), "Lean production, six sigma quality, TQM and company culture", The TQM Magazine, pp. 263-281.

de Koning, H., Does, R.J. and Bisgaard, S. (2008), "Lean Six Sigma in financial services", International Journal of Six Sigma and Competitive Advantage, Vol. 4 No. 1, pp. 1-17.

de Koning, H., Verver, J.P.S., van den Heuvel, J., Bisgaard, S. and Does, R.J.M.M. (2006). "Lean Six Sigma in Healthcare", Journal for Healthcare Quality, Vol. 28 No. 2, pp. 4-11.

Eisenhardt, K.M. (1989), "Building Theories from Case Study Research", Academy of Management Review, Vol. 14, pp. 532-550.

Ferng, J. and Price, A.D. (2005), "An exploration of the synergies between Six Sigma, total quality management, lean construction and sustainable construction", International Journal of Six Sigma and Competitive Advantage, Vol. 1 No. 2, pp. 167-187.

Fornari, A. and Maszle, G. (2004), "Lean Six Sigma Leads Xerox", ASQ Six Sigma Forum Magazine, Vol. 3 No. 4, pp. 11-16.

Goh, T.N. (2002), "A Strategic Assessment of Six Sigma", Quality and Reliability Engineering International , Vol. 18 No. 5, pp. 403-410.

Goh, T.N. and Xie, M. (2004), "Improving on the Six Sigma paradigm", The TQM Magazine, Vol. 16 No. 4, pp. 235-240.

Gummesson, E. (1991), Qualitative Methods in Management Research, Thousand Oaks, CA: Sage Publications. 
Hoerl, R. (2004), "One perspective on the future of Six Sigma", International Journal of Six Sigma and Competitive Advantage, Vol. 1 No. 1, pp. 112-119.

Holbeche, L. (1997), Motivating People in Lean Organizations, Oxford: Butterworth-Heinemann.

Karlsson, C. and Åhlström, P. (1996), "The Difficult Path to Lean Product Development", The Journal of Product Innovation Management, Vol. 13 No. 4, pp. 283-295.

Kumar, M., Antony, J., Madu, C.N., Montgomery, D.C. and Park, S.H. (2008), "Common myths of Six Sigma demystified", International Journal of Quality \& Reliability Management, Vol. 25 No. 8, pp. 878-895.

Kumar, M., Antony, J., Singh, R.K., Tiwari, M.K. and Perry, D. (2006), "Implementing Lean Six Sigma in an Indian SME: a case study", Production Planning \& Control, Vol. 17 No. 4, pp. 407-423.

Magnusson, K., Kroslid, D. and Bergman, B. (2003), Six Sigma The Pragmatic Approach, Lund: Studentlitteratur.

Nave, D. (2002). "How To Compare Six Sigma, Lean and the Theory of Constraints", Quality progress, Vol. 35 No. 3, pp. 73-78.

Näslund, D. (2008), "Lean, Six Sigma and Lean sigma: fads or real process improvement methods?", Business Process Management Journal, Vol. 14 No. 3, pp. 269-287.

Pepper, M.P.J. and Spedding, T. A. (2010), "The evolution of Lean Six Sigma", International Journal of Quality \& Reliability Management, Vol. 27 No. 2, pp. 138-155.

Pickrell, G., Lyons, H.J. and Shaver, J. (2005), "Lean Six Sigma implementation case studies", International Journal of Six Sigma and Competitive Advantage, Vol. 1 No. 4, pp. 369-379.

Ricondo, I. and Viles, E. (2005), "Six Sigma and its link to TQM, BPR, Lean and the learning organisation". International Journal of Six Sigma and Competitive Advantage, Vol. 1 No. 3, pp. 323-354.

Saraph, J. V., P.G. Benson, et al. (1989), "An Instrument for Measuring the Critical Factors of Quality", Decision Sciences, Vol. 20 No. 4, p. 810.

Spector, R.E. (2006), "How Constraints Management Enhances Lean and Six Sigma", Supply Chain Management Review, Vol. 10 No. 1, pp. 42-47.

Van den Heuvel, J., Does, R.J. and de Koning, H. (2006), "Lean Six Sigma in a hospital", International Journal of Six Sigma and Competitive Advantage, Vol. 2 No. 4, pp. 377-388.

Womack, J.P. (2006), "Value Stream Mapping", Manufacturing Engineering, Vol. 136 No. 5, pp. 145155. 